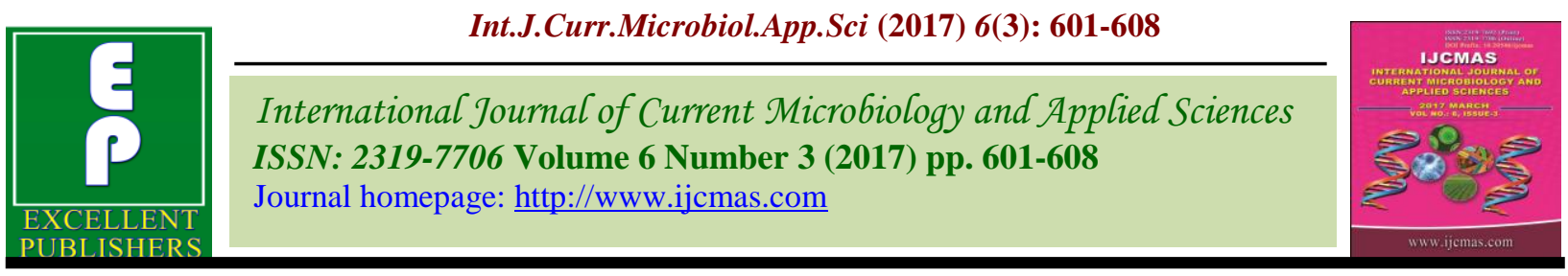

Original Research Article

https://doi.org/10.20546/ijcmas.2017.603.070

\title{
Microbial and Sensory Quality Evaluation of Membrane Processed Sugarcane Juice
}

\author{
Samreen $^{1}$, Ch.V.V. Satyanarayana ${ }^{2}$, L. Edukondalu ${ }^{1}$ and M. Sandhya ${ }^{3}$ \\ ${ }^{1}$ College of Agricultural Engineering, Bapatla, India \\ ${ }^{2}$ College of Food Science and Technology, Bapatla, India \\ ${ }^{3}$ College of Home Science, Guntur, India \\ *Corresponding author
}

\section{A B S T R A C T}

\section{Keywords}

Membrane processing,

Microfiltration,

Ultrafiltration, Poly

Aluminium Chloride,

Permeate flux, Microbial

analysis, Sensory

analysis.

Article Info

Accepted:

10 February 2017

Available Online:

10 March 2017
Sugarcane juice is commonly used as a delicious drink in both urban and rural areas. Sugarcane juice is spoiled quickly due to the presence of simple sugars. Preservation of sugarcane juice was examined to reduce the spoilage and to increase the shelf life by membrane processing. A study was carried out to preserve sugarcane juice by membrane processing and compared with the untreated juice. The results revealed that good quality sugarcane juice of variety CO380 with satisfactory storage stability at refrigeration could be prepared by microfiltration and pasteurization of sugarcane juice with addition of flocculant. The permeate flux of microfiltered and pasteurized sugarcane juice with addition of flocculant decreased from 9.14 to $6.53 \mathrm{~L} / \mathrm{h} \mathrm{m}^{2}$. Microbial analysis indicated by yeast count, mould count and total plate count revealed that preheated and pasteurized juice and microfiltered and pasteurized juice with addition of PAC and without addition of PAC are relatively better. Sensory evaluation indicated that the microfiltered and pasteurized juice with addition of PAC followed by only thermal treated juice scored highest rating on hedonic scale by panelists in terms of appearance (8.0), flavour (8.16) and overall acceptability (8.0). The colour values generally decreased in all the treatments. Overall based on microbiological and sensory data, it could be concluded that thermal treatment and flocculant added, microfiltered, pasteurized treatments are better in that order, the former being the best. The study suggests that membrane filtration in combination with thermal treatment results in good quality bottled sugarcane juice.

\section{Introduction}

Sugarcane (Saccharum officinarum L.) is an important industrial crop cultivated in tropical and subtropical regions of the world. India is the world second largest producer of sugarcane next to Brazil. Sugarcane has been used as a sweetener for millennia and today refined sugar is used in copious quantities to supplement the natural sugar found in fruits and vegetables. A part of sugarcane juice is consumed as inexpensive and pleasing beverages in India. It possesses therapeutic value. Sugarcane juice is commonly used as a delicious drink in both urban and rural areas. Sugarcane juice of $100 \mathrm{ml}$ provides $40 \mathrm{Kcal}$ of energy, $10 \mathrm{mg}$ of iron and $6 \mu \mathrm{g}$ of carotene. Sugarcane juice is rich in enzymes and has many medicinal properties. It contains water (75\%-85\%), reducing sugar (0.3-3.0\%) and non-reducing sugar (10-21\%). Sugarcane juice is a great preventive and healing source for sore throat, cold and flu. Even the diabetic can enjoy this sweet drink without worrying 
about calories. It hydrates the body quickly when exposed to prolonged heat and physical activity. It is an excellent substitute for aerated drinks and colas; it refreshes and energizes the body (Ashish et al., 2012). Due to its commercial importance, it is envisaged that sugarcane juice production can become a profitable business provided efforts are made to preserve its fresh quality during storage (Krishnakumar et al., 2013).

In general sugarcane juice is spoiled quickly due to the presence of simple sugars. Soon after the harvest of sugarcane, endogenous invertase enzyme is activated and acts as a cause of deterioration. These enzymes lead to inversion of sucrose and affect the quality of sugar. The polyphenol oxidase is the major enzyme involved in the discoloration of sugarcane juice which can be improved by heat inactivation of enzyme. The sugarcane juice can be introduced as delicious beverage by preventing the spoilage of juice with appropriate preservation method. One of the processes used to enable the commercialization of sugar cane juice is the clarification which can be achieved through two methods, one the conventional filtration method and the other membrane separation method.

The membrane separation processes such as Microfiltration (MF), Ultrafiltration (UF), Nanofiltration (NF) and Reverse osmosis (RO) are promising novel alternative nonthermal and non-chemical methods that are relatively less energy intensive and retain heat labile components. MF and UF offer excellent potential in food industry for clarification and pasteurization to replace conventional techniques. MF is the separation process with membranes similar to classical filtration to retain material that are larger than pore size and permeate as the desired product. UF can be used to produce further clarified juice and also free of microbes as they are larger than molecular weight cutoff of most UF membranes. Therefore, both UF and MF can potentially replace thermal processing and give better quality juice with good sensory attributes. These processes have several advantages such as energy efficiency, selectivity, simplicity of operation, and reduced consumption of chemicals. Therefore, an attempt was made to explore a non-thermal or combination of thermal and membrane filtration process to produce high quality bottled sugarcane juice. Studies were conducted using fresh sugarcane juice with the objective to explore the possibility of replacing preheating operation in thermal treatment using microfiltration and to develop a process technology for preservation of sugarcane juice by membrane processing.

\section{Materials and Methods}

The raw materials i.e. Sugarcane CO380 variety was obtained from a local farmer of Thoreddu village, East Godavari district, Andhra Pradesh. Sodium Benzoate, Poly Aluminium Chloride (PAC), bottles of $250 \mathrm{ml}$ capacity were procured from the market. Sugarcane stems with good quality and without any pest or disease infestation were selected and peeled for juice extraction. Sugarcane juice crusher, Hot air oven, autoclave, Hollow Fibre Membrane Setup (Model HFM-01, IIT Kharagpur), Crown corking machine, Hunterlab color flex meter (M/S. Hunterlab, Reston, VA, USA, and Model CFLX-45).

The colour was expressed as Chroma value (Lo et al., 2007). It can be measured by Chroma $=\left(\mathrm{a}^{* 2}+\mathrm{b}^{*^{2}}\right)^{1 / 2}$. The presence of microorganisms in the processed sugar cane juice was determined by performing Total Plate Count methods (to enumerate the growth of coliforms and other bacteria), mould count (to enumerate the growth of fungi) and yeast count (to enumerate the growth of yeast). 
Sugarcane juice was extracted by power operated two horizontal roller type juice extractor and filtered through the muslin cloth to remove the extraneous matter. The juice formulation was done by the addition of ginger extract and lemon extract to sugarcane juice in proper concentration as stated below and the samples were refrigerated. The prepared mixture of ginger extract, lemon juice and sugarcane juice was filtered through muslin cloth and is subsequently used as a raw material for processing. This mixture is referred as sugarcane juice here after. Flocculation was done for $T_{2}$ treatment prior to microfiltration shown in table 1 . Membrane processing was carried out in hollow fiber membrane module setup shown in figure 1 .

Fig.1 Schematic diagram of the hollow fiber membrane module setup

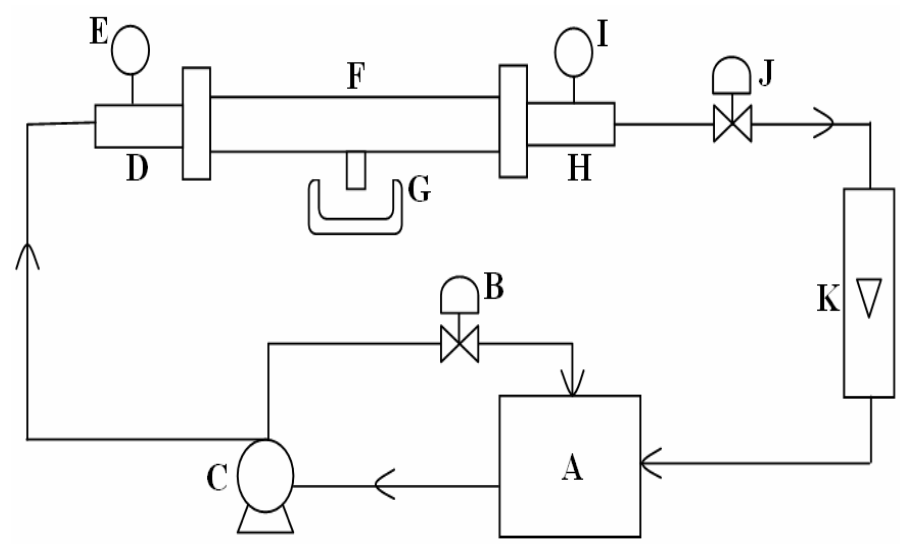

Where,

A: Feed Tank, B: Bypass Valve, C: Booster Pump, D: Short piece, E: Upstream Pressure gauge $\left(0-4.21 \mathrm{~kg} / \mathrm{cm}^{2}(60 \mathrm{psi})\right)$, F: Hollow Fiber Module, G: Permeate Collector, H: Short Piece, I: Downstream Pressure Gauge $\left(0-4.21 \mathrm{~kg} / \mathrm{cm}^{2}(60 \mathrm{psi})\right)$, J: Pressure valve (Needle type), K: Rotameter ( $0-50 \mathrm{lph})$.

The permeate flux was calculated as

$J *=(1 / A) *(d v / d t)$

Where $\mathrm{J}^{*}=$ permeate flux $\left(\mathrm{L} / \mathrm{h} \mathrm{m}^{2}\right)$

$\mathrm{A}=$ area of the membrane $\left(\mathrm{m}^{2}\right)$

$\mathrm{dv}=$ volume of flow rate $(\mathrm{L})$

$\mathrm{dt}=$ time of flow rate $(\mathrm{h})$

The different treatments which were given to the sugarcane juice are explained in table 1 .

\section{Results and Discussion}

\section{Changes in microbiological quality of stored sugarcane juice}

There was no yeast count found initially in pasteurized, microfiltered pasteurized and PAC added microfiltered pasteurized juices. Then it increased to $1 \times 10^{6} \mathrm{CFU} / 10 \mathrm{ml}$ in storage. This may be due to thermal treatment and addition of preservative sodium benzoate. In treatments $T_{4}$ and $T_{5}$ the yeast count was observed to be $2 \times 10^{6} \mathrm{CFU} / 10 \mathrm{ml}$. In treatment $\mathrm{T}_{6}$ higher colonies were observed (Table 2). Chauhan et al. (2002) also reported similar microbial changes in pasteurized stored sugarcane juice.

The mould count indicated no growth in all treated samples and in Sample $\mathrm{T}_{6}$ it was $1 \mathrm{x}$ $10^{6} \mathrm{CFU} / 10 \mathrm{ml}$ and increased to $3 \times 10^{6}$ 
CFU/10 $\mathrm{ml}$ on $12^{\text {th }}, 16^{\text {th }}$ and $20^{\text {th }}$ days. The mould count for treatments $\mathrm{T}_{1}, \mathrm{~T}_{2}, \mathrm{~T}_{3}$ was $1 \mathrm{x}$ $10^{6} \mathrm{CFU} / 10 \mathrm{ml}$ and remained same upon storage also. In treatments $T_{4}$ and $T_{5}$ it was observed to be $1 \times 10^{6} \mathrm{CFU} / 10 \mathrm{ml}$ and $2 \mathrm{x}$ $10^{6} \mathrm{CFU} / 10 \mathrm{ml}$ respectively. However, it increased to $2 \times 10^{6} \mathrm{CFU} / 10 \mathrm{ml}$ on $12^{\text {th }}, 16^{\text {th }}$ and $20^{\text {th }}$ days (Table 3 ). Similar observations were made by Chauhan et al., (2002).

The total plate count (TPC) was observed to be more in treatment $\mathrm{T}_{6}$ upon storage. TPC was observed to be less for samples $T_{1}$ and $\mathrm{T}_{2}$. Initially there no growth then increased from $1 \times 10^{6} \mathrm{CFU} / 10 \mathrm{ml}$ on 12th day to $2 \mathrm{x}$ $10^{6} \mathrm{CFU} / 10 \mathrm{ml}$ on 20 th day. The treatment $\mathrm{T}_{3}$ had standard count of $1 \times 10^{6} \mathrm{CFU} / 10 \mathrm{ml}$ on $0^{\text {th }}$ day to $3 \times 10^{6} \mathrm{CFU} / 10 \mathrm{ml}$ on $20^{\text {th }}$ day. The treatment $\mathrm{T}_{4}$ had TPC of $2 \times 10^{6} \mathrm{CFU} /$ $10 \mathrm{ml}$ on 0th day to $4 \times 10^{6} \mathrm{CFU} / 10 \mathrm{ml}$ on $20^{\text {th }}$ day. The treatment $\mathrm{T}_{5}$ had TPC of $2 \times 10^{6}$ $\mathrm{CFU} / 10 \mathrm{ml}$ on 0th day to $4 \times 10^{6} \mathrm{CFU} / 10$ $\mathrm{ml}$ on $20^{\text {th }}$ day (Table 4). Chauhan et al., (2002) reported similar observations during storage of juice.

\section{Sensory Evaluation of sugarcane juice samples}

Sensory evaluation of treatments was carried out for consumer acceptance and preference using 10 untrained panelists selected at random. Appearance, flavour, overall acceptability of the samples were rated using a 9-point Hedonic scale where 9 and 1 represent like extremely and dislike extremely respectively. Sensory evaluation was carried out at ambient conditions in a comfortable and quiet area without disturbance under fluorescent lighting. Water was supplied to cleanse palate between samples.

Table.1 Different treatments given in sugarcane juice processing

\begin{tabular}{|c|c|c|c|c|}
\hline $\begin{array}{c}\text { Treatment } \\
\text { code }\end{array}$ & Treatment & Method & $\begin{array}{c}\text { MEMBRAN } \\
\text { E }\end{array}$ & PRESSURE \\
\hline $\mathrm{T}_{1}$ & $\begin{array}{l}\text { Preheated and } \\
\text { pasteurised juice }\end{array}$ & $\begin{array}{l}\text { Juice was preheated at } 50^{\circ} \mathrm{C} \text {, } \\
10 \text { min and pasteurised at } \\
80^{\circ} \mathrm{C}, 5 \text { min and sodium } \\
\text { benzoate was added }\end{array}$ & - & - \\
\hline $\mathrm{T}_{2}$ & $\begin{array}{l}\text { Microfiltered and } \\
\text { pasteurised juice }\end{array}$ & $\begin{array}{l}\text { Juice was Microfiltered and } \\
\text { pasteurised at } 80^{\circ} \mathrm{C}, 5 \mathrm{~min}\end{array}$ & $0.2 \mu \mathrm{m}(\mathrm{PAN})$ & $\begin{array}{c}1.05 \mathrm{~kg} / \mathrm{cm}^{2}(15 \\
\mathrm{psi})\end{array}$ \\
\hline $\mathrm{T}_{3}$ & $\begin{array}{l}\text { Microfiltered and } \\
\text { pasteurised juice } \\
\text { with addition of } \\
\text { PAC }\end{array}$ & $\begin{array}{l}\text { Addition of PAC before MF } \\
\text { to juice, microfiltered and } \\
\text { pasteurised at } 80^{\circ} \mathrm{C}, 5 \mathrm{~min}\end{array}$ & $0.2 \mu \mathrm{m}(\mathrm{PAN})$ & $\begin{array}{c}1.05 \mathrm{~kg} / \mathrm{cm}^{2}(15 \\
\mathrm{psi})\end{array}$ \\
\hline $\mathrm{T}_{4}$ & $\begin{array}{l}\text { Ultrafiltration of } \\
\text { microfiltered juice } \\
\text { permeate at } 2.10 \\
\mathrm{~kg} / \mathrm{cm}^{2}(30 \mathrm{psi})\end{array}$ & $\begin{array}{l}\text { Ultrafiltration of } \\
\text { microfiltered permeate juice, } \\
\text { non-thermal, no preservative } \\
\text { was added }\end{array}$ & $\begin{array}{l}\text { MF- } \\
0.2 \mu \mathrm{m}(\mathrm{PAN}) \\
\text { UF- } \\
70 \mathrm{kDa}(\mathrm{PS})\end{array}$ & $\begin{array}{l}\text { MF- } 1.05 \mathrm{~kg} / \mathrm{cm}^{2} \\
\quad(15 \mathrm{psi}) \\
\mathrm{UF}-2.10 \mathrm{~kg} / \mathrm{cm}^{2} \\
(30 \mathrm{psi})\end{array}$ \\
\hline $\mathrm{T}_{5}$ & $\begin{array}{l}\text { Ultrafiltration of } \\
\text { microfiltered juice } \\
\text { permeate at } 3.16 \\
\mathrm{~kg} / \mathrm{cm}^{2}(45 \mathrm{psi})\end{array}$ & $\begin{array}{l}\text { Ultrafiltration of } \\
\text { microfiltered permeate juice, } \\
\text { non-thermal, no preservative } \\
\text { was added }\end{array}$ & $\begin{array}{l}\text { MF- } \\
0.2 \mu \mathrm{m}(\mathrm{PAN}) \\
\text { UF- } \\
70 \mathrm{kDa}(\mathrm{PS})\end{array}$ & $\begin{array}{l}\text { MF- } 1.05 \mathrm{~kg} / \mathrm{cm}^{2} \\
\quad(15 \mathrm{psi}) \\
\text { UF- } 3.16 \mathrm{~kg} / \mathrm{cm}^{2} \\
\quad(45 \mathrm{psi})\end{array}$ \\
\hline $\mathrm{T}_{6}$ & Control & no treatment was given & - & - \\
\hline
\end{tabular}

PAN : Poly Acrylo Nitrile

PS : Polysulphone 
Table.2 Yeast count of different treatments of sugarcane juice during storage

\begin{tabular}{|c|c|c|c|c|c|c|}
\hline \multirow{2}{*}{$\begin{array}{c}\text { Storage } \\
\text { period, } \\
\text { days }\end{array}$} & \multicolumn{7}{|c|}{ Yeast count (x 10 $\mathbf{6}$ CFU / 10 ml of sample) } \\
\cline { 2 - 7 } & $\mathbf{T}_{\mathbf{1}}$ & $\mathbf{T}_{\mathbf{2}}$ & $\mathbf{T}_{\mathbf{3}}$ & $\mathbf{T}_{\mathbf{4}}$ & $\mathbf{T}_{\mathbf{5}}$ & $\mathbf{T}_{\mathbf{6}}$ \\
\hline 0 & - & - & - & 2 & 2 & 3 \\
\hline 4 & 1 & 1 & 1 & 2 & 2 & 3 \\
\hline 8 & 1 & 1 & 1 & 2 & 2 & 3 \\
\hline 12 & 1 & 1 & 1 & 2 & 2 & 3 \\
\hline 16 & 1 & 1 & 1 & 2 & 2 & 3 \\
\hline 20 & 1 & 1 & 1 & 2 & 2 & 3 \\
\hline
\end{tabular}

$\mathrm{T}_{1}$ - thermal treatment (pre-treatment $50^{\circ} \mathrm{C}, 10 \mathrm{~min}$ ) +pasteurization at $80^{\circ} \mathrm{C}, 5 \mathrm{~min}+$ preservative; $\mathrm{T}_{2}$ - microfiltration $\left[0.2 \mu \mathrm{m}, 1.05 \mathrm{~kg} / \mathrm{cm}^{2}(15 \mathrm{psi})\right]+$ pasteurization at $80^{\circ} \mathrm{C}, 5 \mathrm{~min}+$ preservative; $\mathrm{T}_{3}-\mathrm{PAC}+$ microfiltration $[0.2 \mu \mathrm{m}, 1.05$ $\left.\mathrm{kg} / \mathrm{cm}^{2}(15 \mathrm{psi})\right]+$ pasteurization at $80^{\circ} \mathrm{C}, 5 \mathrm{~min}+$ preservative; $\mathrm{T}_{4^{-}}$microfiltration $\left[0.2 \mu \mathrm{m}, 1.05 \mathrm{~kg} / \mathrm{cm}^{2}(15 \mathrm{psi})\right]$ +ultrafiltration [70 kDa, $\left.2.10 \mathrm{~kg} / \mathrm{cm}^{2}(30 \mathrm{psi})\right] ; \mathrm{T}_{5^{-}}$microfiltration $\left[0.2 \mu \mathrm{m}, 1.05 \mathrm{~kg} / \mathrm{cm}^{2}(15 \mathrm{psi})\right]+$ ultrafiltration $[70$ $\left.\mathrm{kDa}, 3.16 \mathrm{~kg} / \mathrm{cm}^{2}(45 \mathrm{psi})\right] ; \mathrm{T}_{6}$ - control

Table.3 Mould count of different treatments of sugarcane juice during storage

\begin{tabular}{|c|c|c|c|c|c|c|}
\hline \multirow{2}{*}{$\begin{array}{c}\text { Storage } \\
\text { period, } \\
\text { Days }\end{array}$} & \multicolumn{7}{|c|}{ Mould count (x 10 $\mathbf{6}$ CFU / 10 ml of sample) } \\
\cline { 2 - 7 } & $\mathbf{T}_{\mathbf{1}}$ & $\mathbf{T}_{\mathbf{2}}$ & $\mathbf{T}_{\mathbf{3}}$ & $\mathbf{T}_{\mathbf{4}}$ & $\mathbf{T}_{\mathbf{5}}$ & $\mathbf{T}_{\mathbf{6}}$ \\
\hline 0 & - & - & - & - & - & 1 \\
\hline 4 & 1 & 1 & 1 & 1 & 2 & 2 \\
\hline 8 & 1 & 1 & 1 & 1 & 2 & 2 \\
\hline 12 & 1 & 1 & 1 & 2 & 2 & 3 \\
\hline 16 & 1 & 1 & 1 & 2 & 2 & 3 \\
\hline 20 & 1 & 1 & 1 & 2 & 2 & 3 \\
\hline
\end{tabular}

$\mathrm{T}_{1}$ - thermal treatment (pre-treatment $50^{\circ} \mathrm{C}, 10 \mathrm{~min}$ ) +pasteurization at $80^{\circ} \mathrm{C}, 5 \mathrm{~min}$ +preservative; $\mathrm{T}_{2}$ - microfiltration $\left[0.2 \mu \mathrm{m}, 1.05 \mathrm{~kg} / \mathrm{cm}^{2}(15 \mathrm{psi})\right]+$ pasteurization at $80^{\circ} \mathrm{C}, 5 \mathrm{~min}+$ preservative; $\mathrm{T}_{3}-\mathrm{PAC}+$ microfiltration $[0.2 \mu \mathrm{m}, 1.05$ $\left.\mathrm{kg} / \mathrm{cm}^{2}(15 \mathrm{psi})\right]+$ pasteurization at $80^{\circ} \mathrm{C}, 5 \mathrm{~min}+$ preservative; $\mathrm{T}_{4^{-}}$microfiltration $\left[0.2 \mu \mathrm{m}, 1.05 \mathrm{~kg} / \mathrm{cm}^{2}(15 \mathrm{psi})\right]$ +ultrafiltration [70 kDa, $\left.2.10 \mathrm{~kg} / \mathrm{cm}^{2}(30 \mathrm{psi})\right] ; \mathrm{T}_{5^{-}}$microfiltration $\left[0.2 \mu \mathrm{m}, 1.05 \mathrm{~kg} / \mathrm{cm}^{2}(15 \mathrm{psi})\right]+$ +ultrafiltration $[70$ $\left.\mathrm{kDa}, 3.16 \mathrm{~kg} / \mathrm{cm}^{2}(45 \mathrm{psi})\right] ; \mathrm{T}_{6}$ - control

Table.4 Total plate count of different treatments of sugarcane juice during storage

\begin{tabular}{|c|c|c|c|c|c|c|}
\hline \multirow{2}{*}{$\begin{array}{c}\text { Storage } \\
\text { period, } \\
\text { days }\end{array}$} & \multicolumn{7}{|c|}{ Total plate count (x 10 $\mathbf{6}$ CFU / 10 ml of sample) } \\
\cline { 2 - 7 } & $\mathbf{T}_{\mathbf{1}}$ & $\mathbf{T}_{\mathbf{2}}$ & $\mathbf{T}_{\mathbf{3}}$ & $\mathbf{T}_{\mathbf{4}}$ & $\mathbf{T}_{\mathbf{5}}$ & $\mathbf{T}_{\mathbf{6}}$ \\
\hline 0 & - & - & 1 & 2 & 2 & 3 \\
\hline 4 & - & - & 1 & 2 & 2 & 3 \\
\hline 8 & - & - & 2 & 2 & 2 & 3 \\
\hline 12 & 1 & 1 & 2 & 4 & 2 & 4 \\
\hline 16 & 1 & 1 & 3 & 4 & 3 & 4 \\
\hline 20 & 1 & 2 & 3 & 4 & 4 & 5 \\
\hline
\end{tabular}

$\mathrm{T}_{1}$ - thermal treatment (pre-treatment $50^{\circ} \mathrm{C}, 10 \mathrm{~min}$ ) +pasteurization at $80^{\circ} \mathrm{C}, 5 \mathrm{~min}+$ preservative; $\mathrm{T}_{2}$ - microfiltration $\left[0.2 \mu \mathrm{m}, 1.05 \mathrm{~kg} / \mathrm{cm}^{2}(15 \mathrm{psi})\right]+$ pasteurization at $80^{\circ} \mathrm{C}, 5 \mathrm{~min}$-preservative; $\mathrm{T}_{3}-\mathrm{PAC}+$ microfiltration $[0.2 \mu \mathrm{m}, 1.05$ $\left.\mathrm{kg} / \mathrm{cm}^{2}(15 \mathrm{psi})\right]+$ pasteurization at $80^{\circ} \mathrm{C}, 5 \mathrm{~min}+$ preservative; $\mathrm{T}_{4^{-}}$microfiltration $\left[0.2 \mu \mathrm{m}, 1.05 \mathrm{~kg} / \mathrm{cm}^{2}(15 \mathrm{psi})\right]$ +ultrafiltration [70 kDa, $\left.2.10 \mathrm{~kg} / \mathrm{cm}^{2}(30 \mathrm{psi})\right] ; \mathrm{T}_{5^{-}}$microfiltration $\left[0.2 \mu \mathrm{m}, 1.05 \mathrm{~kg} / \mathrm{cm}^{2}(15 \mathrm{psi})\right]+$ ultrafiltration $[70$ $\left.\mathrm{kDa}, 3.16 \mathrm{~kg} / \mathrm{cm}^{2}(45 \mathrm{psi})\right] ; \mathrm{T}_{6}$ - control 
Fig.2 Appearance values of different treatments of sugarcane juice during storage

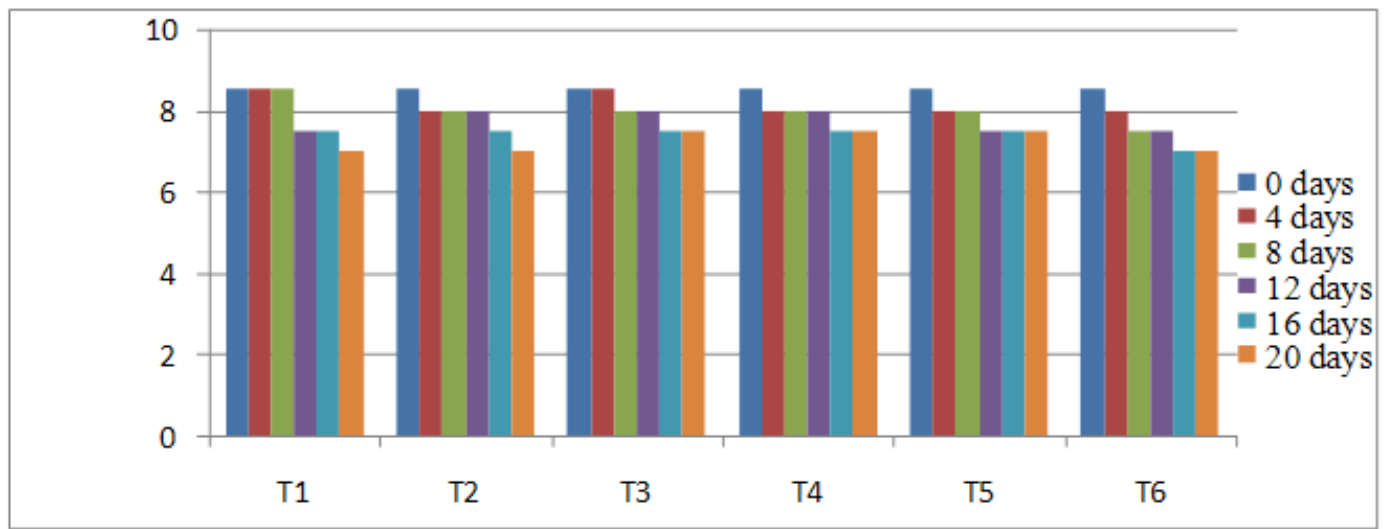

Fig.3 Flavour values of different samples of sugarcane juice during storage

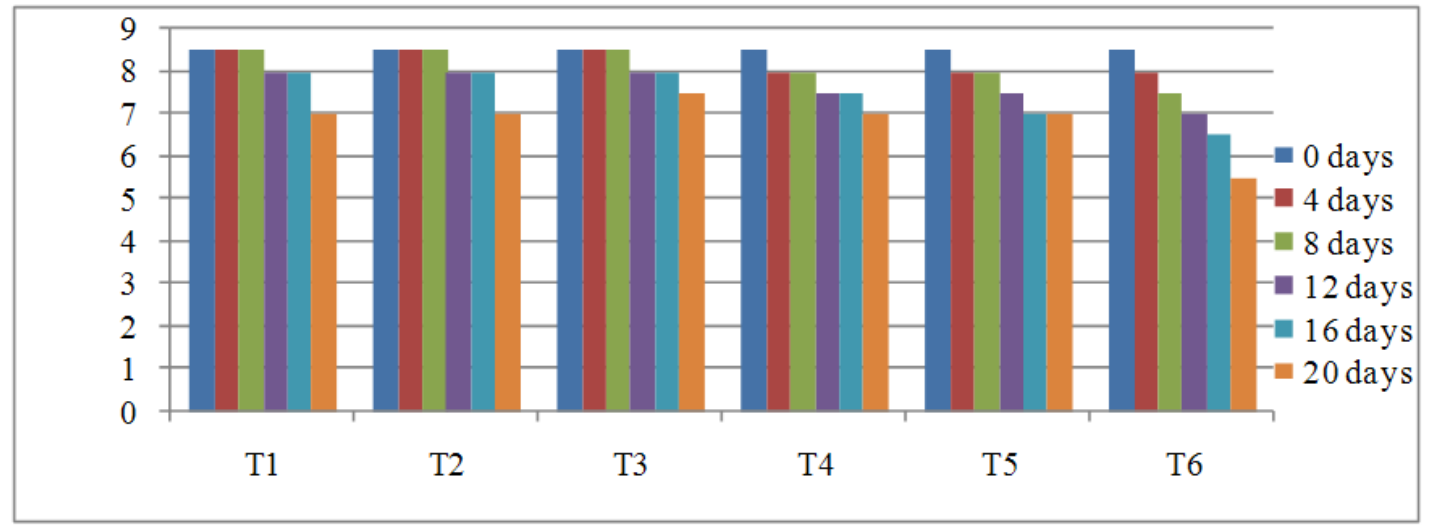

Fig.4 Overall acceptability values of different treatments of sugarcane juice during storage

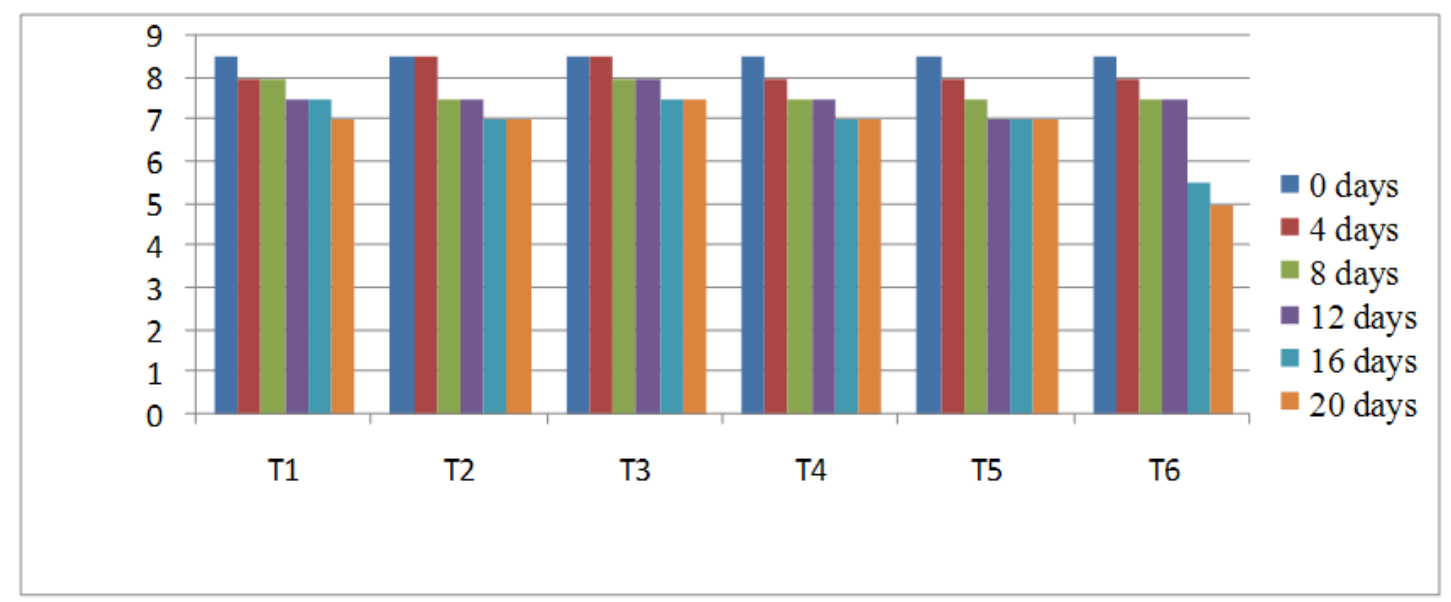


The sugarcane juice samples which were membrane filtered and thermally processed and evaluated by panelists. Appearance rating has been compiled (Fig. 2). The treatment $\mathrm{T}_{3}$, PAC added, microfiltration of sugarcane juice using $0.2 \mu \mathrm{m}$ pore size, at pressure $15 \mathrm{psi}$ scored highest rating on hedonic scale than other treatments.

Similarly the evaluated data assessed by panel of experts for establishing flavour rating was also compiled (Fig. 3). The treatment $\mathrm{T}_{3}$, PAC added, microfiltered and pasteurized scored highest rating on hedonic scale than other samples.

Similarly the evaluated data assessed by panelists for establishing overall acceptability rating has been compiled (Fig. 4). The treatment $\mathrm{T}_{3}, \mathrm{PAC}$ added, microfiltered and pasteurized scored highest rating on hedonic scale than other treatments. Overall based on the experimental data, it can be concluded that among all the treatments $\mathrm{T}_{1}$ and $\mathrm{T}_{3}$ exhibited good physico-chemical, microbiological and sensory properties for the processed sugarcane juice upon storage. The data indicated that membrane filtration in combination with thermal processing is an alternative to existing thermal processing as the quality attributes are relatively better.

In conclusion, the results revealed that good quality sugarcane juice of variety CO380 with satisfactory storage stability at refrigeration could be prepared by microfiltration and pasteurization of sugarcane juice with addition of flocculant. The permeate flux of microfiltered and pasteurized sugarcane juice with addition of flocculant decreased from 9.14 to $6.53 \mathrm{~L} / \mathrm{h} \mathrm{m}^{2}$ with time. The colour values generally decreased in all the treatments. In microbial analysis, Yeast, Mould and Total Plate Count were observed to be less in microfiltered and pasteurised with and without addition of PAC treatments.
Sensory evaluation indicated that the microfiltered and pasteurized juice with addition of PAC followed by only thermal treated juice scored highest rating on hedonic scale by panelists in terms of appearance (8.0), flavour (8.16) and overall acceptability (8.0). It can be concluded that membrane processing of sugarcane juice is one of the alternate methods in combination with thermal processing for producing quality juice.

\section{References}

Ashish, K., Apoorva, B.L., Anurag, S and Amit, P.S. 2012. Shelflife Enhancement of Sugarcane Juice. Croatian J. Food Technol. Biotechnol. Nutri., 7(3): 179-183.

Blatt, W.F., Dravid, A., Michaels, A.S and Nelsen, L. 1970. Solute Polarization and cake formation in membrane ultrafltration: causes, consequences, and control techniques. Membrane Sci. Technol., 47-97.

Bottino, A., Capannelli, G., Turchini, A., Della Valle, P and Trevisan, M.2002. Integrated membrane processes for the concentration of tomato juice. Desalination, 148: 73-77.

Cappannelli, G., Bottino, A., Munari, S., Ballarino, G., Mirzaian, H., Rispoli, G., Lister, D.G. and Maschino, G. 1992. Ultrafiltration of Fresh Orange and Lemon Juices, 25: 518-522.

Chilukuri, V.V.S., Marshall, A.D., Munro, P.A and Singh, H. 2001. Influence of permeate flux and calcium on membrane fouling during crossflow microfiltration of bovine serum albumin solutions. Proceedings of the third New Zealand post graduate conference for Engg. and Technology students, 130134.

Chauhan, O.P., Dheer, S., Tyagi, S.M and Balyan, D.K. 2002. Studies on 
preservation of sugarcane juice. Int. J. Food Properties, 5(1): 217-229.

Fennema, O.R. 1976. Principles of Food Science, Publisher-CRC press, Marcel Dekker Inc. New York-Basel.

Katia, R., Leo, S., Frederico, M.P., Rodrigo, R.P. and José, C.C.P. 2014. Cross flow microfiltration of sugarcane juice effects of processing conditions and juice quality. J. Food Sci. Technol., 34(1): 210-217.

Krishnakumar, T., Thamilselvi $\mathrm{C}$ and Devadas, C.T. 2013. Effect of delayed extraction and storage on quality of sugarcane juice. African J. Agri. Res., 8(10): 930-935.

Lo, W.M., Chua,L.S.T., Al-Kharki,A.F and Azhar,M.E.2007. Evaluantion of freezeconcentrated Sugar-cane juice. J. Trop. Agri. Food Sci. School of Industrial Technology University Sains Malaysia Minden, Pinang, Malaysia, 35(1): 121129.

Naseem, U., Javid, A., Asfandyar, K., Farhat,
A.K., Muhammad, K. and Abdus Salam. 2012. Comparative Microbiological Quality Evaluation of Un-Branded street vended and Branded Juices Sold in Retail outlet of Peshawar City Pakistan. J. Pharmacy Res., 5(12): 5564-5567.

Ranganna, S. 1986. Hand book analysis and quality control for fruit and vegetable products. Publisher - Tata McGraewHill, New Delhi. 182-189, 872-879.

Richa, K., Amit, K.G. and Hiranmoy, G. 2010. Study on the nutritional and microbiological changes of sugarcane juice and determination of optimum conditions during pasteurization. Asian J. Food and Agro-Industry, 3(04): 453461.

Rosa, M., Ricardo, O. and Sueli, B. 2012. Comparison between microfiltration and addition of coagulating agents in the clarification of sugar cane juice. Acta Scientiarum. Technol., 34(4): 413419.

\section{How to cite this article:}

Samreen, Ch.V.V. Satyanarayana, L. Edukondalu and Sandhya, M. 2017. Microbial and Sensory Quality Evaluation of Membrane Processed Sugarcane Juice. Int.J.Curr.Microbiol.App.Sci. 6(3): 601-608. doi: https://doi.org/10.20546/ijcmas.2017.603.070 